\title{
THE ANTIOXIDATIVE AND ANTIMICROBIAL ACTIVITY OF THE AQUEOUS EARTH SMOKE (Fumaria officinalis L.) EXTRACT
}

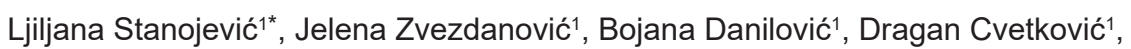
Jelena Stanojević ${ }^{1}$, Dušica Ilić ${ }^{2}$, Milorad Cakić ${ }^{1}$

(ORIGINAL SCIENTIFIC PAPER) UDC 582.675.5:615.322:66.061

${ }^{1}$ University of Niš, Faculty of Technology, Leskovac, Serbia

${ }^{2}$ Research \& Development Center "ALFATEC" doo, Niš, Serbia

Earth smoke herb (Fumaria officinalis L.) was used as a source of extractive matter in this study. The aqueous extract was obtained by pouring boiling water over the plant material $(1: 20 \mathrm{~m} / \mathrm{v})$ and letting it stay for 90 minutes at room temperature. The identification of bioactive compounds in the extract was performed using the UHPLC-DAD-ESI-MS analysis. The content of total phenols and total flavonoids was determined spectrophotometrically by Folin-Ciocalteu and $\mathrm{AlCl}_{3}$ methods, respectively. The antioxidant activity of the extract was also investigated spectrophotometrically by DPPH and ABTS assays. A disc-diffusion method was used in the antimicrobial activity investigation on the following pathogenic microorganisms: Candida albicans, Proteus vulgaris, Pseudomonas aeruginosa, Bacillus subtilis, Staphylococcus aureus, Escherichia coli and Klebsiella pneumoniae. Seven components were detected in the obtained extract, while caffeic and rosmarinic acid were identified. The main component in the extract was rosmarinic acid (16.7 g/100 g of dry extract). The content of total phenols was $77.67 \mathrm{mg} \mathrm{GAE} / \mathrm{g}$ of the dry extract while the content of total flavonoids was $21.21 \mathrm{mg} \mathrm{RE} / \mathrm{g}$ of the dry extract. The extract concentrations required to neutralize $50 \%$ of the initial DPPH radical concentration were 7.38 and $8.18 \mu \mathrm{g} / \mathrm{cm}^{3}$ after 30 and 20 min of incubation, respectively, as well as $48.6 \mu \mathrm{g} / \mathrm{cm}^{3}$ with no incubation. The extract concentration required to neutralize $50 \%$ of the initial ABTS radical concentration was $96.0 \mu \mathrm{g} / \mathrm{cm}^{3}$. The obtained extract has shown the highest antimicrobial activity against Candida albicans fungus. The presented results indicate that the aqueous earth smoke extract should be rightly considered as a potential source of natural antioxidants and antimicrobial agents.
Keywords: Fumaria officinalis L., Earth smoke aqueous extract, Antioxidant activity, Antimicrobial activity, Rosmarinic acid.

\section{Introduction}

Medicinal herbs are a source of secondary metabolites with numerous biological and pharmacological properties. Many natural products that originate from plants have antioxidant and antimicrobial properties and can protect human body from free radicals and pathogens. The antioxidant activity of plant extracts is often caused by the presence of polyphenolic compounds in medicinal herbs. For this purpose, it is necessary to characterize different plant extracts in order to use them as natural antioxidants and antimicrobial agents in food or medical preparations [1].

Earth smoke (Fumaria officinalis L.) belongs to the Papaveraceae family of Fumaria genus. It is a annual leafy plant, about $60 \mathrm{~cm}$ high of grayish-green color. The alkaloids (up to $1 \%$ of fumarine, aurotensin, etc.), flavonoids, fumaric acid, mucus, choline, etc. have been determined in the earth smoke. Besides this, earth smoke also contains sodium, potassium, calcium, tannins, resins, sugar, mucus and bitter substances. Earth smoke is used as diuretic, diaphoretic, hypotensive and tonic. It is especially recommended for chronic eczema, even for psoriasis [2,3,4].
There are data that prove the antioxidant and antimicrobial activity of methanolic [1], as well as the antimicrobial activity of ethanolic extracts of the earth smoke herb originating from Turkey [5]. Ivanov and coworkers (2014) have proven the antioxidant activity of ten ethanolic extracts from different species of Fumaria genus ( $F$. officinalis L., $F$. thuretii Boiss., F. kralikii Jord., F. rostellata Knaf., F. schrammii (Asch.) Velen., F. parviflora Lam., F. densiflora DC., F. petteri Rchb., F. vaillanti Loisel. i F. schleicherii Soy.-Will.) originating from the Bulgaria territory [6].

Biological activities of earth smoke are probably the result of the presence of alkaloids, polyphenols and flavonoids. Phenolic acids are a group of organic compounds widely occurring in plants [7]. The antioxidant activity of phenolic acids particularly depends on their structure, presence and position of substituents on the aromatic ring, as well as on structure of the side chains [8]. Phenolic acids are present in all parts of plants and have many functions (nutrients assimilation, protein synthesis, enzyme activity regulation and photosynthesis). Phenolic acids are mostly

\footnotetext{
*Author address: Ljiljana Stanojević, Faculty of Technology,

Bulevar oslobođenja 124, 16000 Leskovac, Serbia

E-mail: ljiljas76@yahoo.com; stanojevic@tf.ni.ac.rs

The manuscript received: December, 05, 2018.

Paper accepted: December, 14, 2018.
} 
linked by ester, ether or acetal bonds to other plant compounds (cellulose, proteins, lignin, polyphenols) or to small organic molecules (glucose, maleic and tartaric acid) [8].

A positive biological activity of the aerial part of the earth smoke herb is mainly studied $[1,5,6]$. Based on the chemical composition, this plant material should be used in pharmaceutical, cosmetic and food industry as a source of natural antioxidants and antimicrobial agents. But, the available literature does not provide data about the chemical composition and biological activity of the extracts obtained from earth smoke herb that originates in Serbia.

Having this in mind, the main goal of this work was the extraction of aerial parts of the earth smoke herb (Fumariae herba) from Serbia by water with hydromodulus $1: 20 \mathrm{~m} / \mathrm{v}$. Besides this, the identification of bioactive compounds in the obtained extract by UHPLC-DAD-ESI-MS method, the determination of total phenolics by Folin-Ciocalteu and total flavonoids by $\mathrm{AlCl}_{3}$ method, the antioxidant activity by DPPH and ABTS tests and the antimicrobial activity by a disc-diffusion method, have been performed.

\section{Experimental}

\section{Reagents and chemicals}

Folin-Ciocalteu's reagent, gallic acid, rutin, 1,1-diphenyl-2-picrylhydrazyl (DPPH) radical, aluminum (III) chloride hexahydrate, potassium acetate, 2,2'-azinobis (3-ethylbenzothiazoline-6-sulfonic acid) diammonium salt (ABTS), potassium persulphate, butylated hydroxy-toluene (BHT) (Sigma Chemical Company, St. Louis, USA). Water, acetonitrile and formic acid used in liquid chromatographymass spectrometry experiments were of LC-MS grade. All other chemicals were of analytical grade (p.a.).

\section{Plant material}

The air-dried aerial part of the earth smoke herb (Fumaria officinalis L.) (Chamomilla, Banatski Karlovac, Serbia) was used as the extraction material in this study. The plant material was milled in a laboratory disintegrator (laboratory electric mill "BRAUN AROMATIC KSM2"), right before the extraction.

\section{Extraction}

The measured quantity of the milled plant material $(5 \mathrm{~g})$ was poured with boiling water $\left(100 \mathrm{~cm}^{3}\right)$. Extraction was performed for 90 minutes at room temperature (hydromodulus, ratio of water/plant material, was 1:20 m/v). The obtained extract was separated by filtering under a weak vacuum. Finally, it was dried in the vacuum dryer at $40{ }^{\circ} \mathrm{C}$ till constant mass and the content of total extractive matter (TEM, dry extract) was calculated on the basis of the dry residue content. Based on the obtained results, the yield of total extractive matters was calculated in $\mathrm{g}$ per $100 \mathrm{~g}$ of the plant material (g/100g p.m.)

\section{Total phenolics content}

The total phenolics (TP) content, in the aqueous earth smoke extract, was determined spectrophotometrically ac- cording to the Folin-Ciocalteu method [9] by the previously described procedure where gallic acid has been used as a standard compound [10].

Total flavonoids content

The total flavonoids (TF) content in the aqueous earth smoke extract was determined according to the aluminium chloride method [11] by the previously described procedure where rutin has been used as a standard compound [10].

Ultrahigh performance liquid chromatography-diode array-electrospray ionization mass spectrometry (UHPLCDAD-ESI-MS) method

The liquid chromatography (UHPLC) was carried out by using a Dionex Ultimate 3000 UHPLC+ system equipped with a diode array (DAD) detector connected to LCQ Fleet Ion Trap Mass Spectrometer, Thermo Fisher Scientific, the USA. The separations were performed on Hypersil gold C18 column $(50 \times 2.1 \mathrm{~mm}, 1.9 \mu \mathrm{m})$ of the same manufacturer, at $25^{\circ} \mathrm{C}$.

Two solvents, $0.1 \%(\mathrm{v} / \mathrm{v})$ formic acid in water $(\mathrm{A})$ and $0.1 \%(\mathrm{v} / \mathrm{v})$ formic acid in acetonitril $(\mathrm{B})$ was the mobile phase at a flow rate of $0.250 \mathrm{ml} / \mathrm{min}$, used in the following gradient program (Table 1).

Table 1. Gradient program applied in UHPLC-DAD-ESI-MS analysis

\begin{tabular}{lll}
\hline Time, $\min$ & $\begin{array}{l}\text { Mobile phase } \\
(\mathrm{A}), \% \text { vol }\end{array}$ & $\begin{array}{l}\text { Mobile phase } \\
(\mathrm{B}), \% \text { vol }\end{array}$ \\
\hline 0 & 90 & 10 \\
2 & 70 & 30 \\
5 & 60 & 40 \\
7 & 50 & 50 \\
9 & 20 & 80 \\
11 & 10 & 90 \\
12 & 10 & 90 \\
12.1 & 90 & 10 \\
20 & 90 & 10 \\
\hline
\end{tabular}

The injection volume was $1.00 \mu$ l. Electronic absorption UV-VIS spectra were recorded on DAD-detector (with total spectral range, $200-800 \mathrm{~nm}$ ) at four monitoring wavelengths, $\lambda_{\text {mon }}=280,330,360$ and $410 \mathrm{~nm}$. MS-analysis was performed using a LCQ 3D-ion trap mass spectrometer with electrospray ionization (ESI) in the negative ion mode. The ESI-source parameters were set as follows: source voltage $4.5 \mathrm{kV}$, capillary voltage $-41 \mathrm{~V}$, tube lens voltage $-95 \mathrm{~V}$, capillary temperature $350{ }^{\circ} \mathrm{C}$, sheath and auxiliary gas flow $\left(\mathrm{N}_{2}\right) 32$ and 8 arbitrary units, respectively. MSspectra were obtained by the full range acquisition of $\mathrm{m} / \mathrm{z}$ 100-1000. A data dependent scan was performed by deploying the collision-induced dissociation (CID) in MS/MS fragmentation study. The normalized collision energy of CID cell was $12 \mathrm{eV}$.

The undiluted aqueous earth smoke extract in con- 
centration of $11.6 \mathrm{mg} / \mathrm{cm}^{3}$ was diluted 30 times in methanol before subjecting to the chromatographic analysis. The identification of rosmarinic acid was performed according to electron absorption spectra, mass spectra detected molecular ions, specific MS fragmentation (MS/ MS spectra) and comparisons of the obtained spectra with the appropriate spectra of the standard substance, while the concentration of rosmarinic acid in the extract was determined using the adequate calibration curve.

\section{Antioxidant assays}

DPPH-test

The ethanolic solution of DPPH radical $\left(1 \mathrm{ml}, 3 \times 10^{-4}\right.$ $\mathrm{mol} / \mathrm{dm}^{3}$ ) was mixed with $2.5 \mathrm{~cm}^{3}$ of the extract in different concentrations $\left(1.25-40 \mu \mathrm{g} / \mathrm{cm}^{3}\right)$. The procedure was done in three probes. Absorbance at $517 \mathrm{~nm}$ of the first probe was measured immediately, while absorbance of the second and third probe was measured after 20 and 30 min of incubation at room temperature in the dark. The absorbance of pure ethanolic solution of DPPH radical, diluted in an adequate proportion $\left(1 \mathrm{~cm}^{3}\right.$ of DPPH radical, $3 \times 10^{-4} \mathrm{~mol} / \mathrm{dm}^{3}$, diluted with $2.5 \mathrm{~cm}^{3}$ of ethanol "control") was also measured, as well as the absorbance of the extract without the addition of DPPH radical (2.5 $\mathrm{ml}$ of the extract diluted with $1 \mathrm{~cm}^{3}$ of ethanol - "blank"). A free radical scavenging capacity is calculated according to Eq. 1 [12]:

The extent of DPPH radicals neutralization $(\%)=100-\left[\left(A_{U}-A_{B}\right) \times \frac{100}{A_{C}}\right]$...

where $A_{u}$ represents absorbance of the "sample", $A_{b}$ absorbance of the "blank" and $A_{c}$ absorbance of the "control". DPPH test of standard synthetic antioxidant (BHT) was also performed.

\section{ABTS-test}

The modified ABTS test, applicable to lipophilic and hydrophilic compounds was used in this work [13]. ABTS $\bullet+$ radical cation is formed in the reaction of $A B T S$ $\left(7 \times 10^{-3} \mathrm{~mol} / \mathrm{dm}^{3}\right)$ and potassium persulfate $(2.4 \mathrm{mM})$ in $1: 1 \mathrm{v} / \mathrm{v}$ volume ratio, during $12-18 \mathrm{~h}$, at $+4{ }^{\circ} \mathrm{C}$, in the dark (stock solution). After radical formation, the working solution of ABTS was prepared by diluting the stock solution with ethanol - the control factor was the absorbance at $734 \mathrm{~nm}$ reaching the value of 0.7 . ABTS working solution $\left(1.8 \mathrm{~cm}^{3}\right)$ and $2.1 \mathrm{~cm}^{3}$ of ethanol were added in 0.1 $\mathrm{ml}$ of the extract $\left(0.0195-2.5 \mathrm{mg} / \mathrm{cm}^{3}\right)$ and the absorbance of the mixture was measured at $734 \mathrm{~nm}\left(A_{u}\right)$ after 6 minutes of standing in the dark at room temperature. The absorbance was also measured for a diluted ABTS working solution $\left(1.8 \mathrm{~cm}^{3}\right.$ of the working ABTS solution diluted with $2.2 \mathrm{~cm}^{3}$ of ethanol, $\left.A_{K}\right)$ and for the extract before ABTS radical adding $\left(0.1 \mathrm{~cm}^{3}\right.$ of the extract diluted with $3.9 \mathrm{~cm}^{3}$ of ethanol, $A_{B}$ ). Ethanol was used as a blank. The percent of ABTS radical neutralization was calculated using the same equation as for DPPH test [14]. ABTS test of standard synthetic antioxidant (BHT) has also been performed.

All experiments were carried out in three replications and the results represent the mean value \pm standard deviation. The obtained data were analyzed by Microsoft Excel 2007 and Origin 7 trial.

\section{Antimicrobial activity}

The antimicrobial activity was determined against seven microorganisms: Staphylococcus aureus (ATCC 25923), Escherichia coli (ATCC 25922), Proteus vulgaris (ATCC 8427), Candida albicans (ATCC 2091), Pseudomonas aeruginosa (ATTC 2785), Bacillus subtilis (ATCC 6633) and Klebsiella pneumoniae (ATCC 700603). Microorganisms used in this research are part of the collection of the Laboratory of Microbiology at the Faculty of Technology, Leskovac. Nutrition agar (Torlak, Belgrade, Serbia) was used for the cultivation of bacteria, while Sabouraud maltose agar (Torlak, Belgrade, Serbia) was used for the yeast growth. Medium were autoclaved for $15 \mathrm{~min}$ at $121^{\circ} \mathrm{C}$ and $110 \mathrm{kPa}$.

A disc diffusion method was performed as previously described $[15,16]$. The inoculum was prepared by suspending of several identical colonies of the overnight culture of test microorganisms in sterile $0.8 \% \mathrm{NaCl}$. The suspension was well homogenized by vortexing, and turbidity was adjusted in comparison with $0.5 \mathrm{McFar}$ land standard. The standardized suspension containing $1-2 \times 10^{8} \mathrm{CFU} / \mathrm{cm}^{3}$ for bacteria and $1-2 \times 10^{6} \mathrm{CFU} / \mathrm{cm}^{3}$ for the yeast was swabbed on the surface of solidified agar plates in three directions at the angle of $60^{\circ}$. Sterile discs (9 $\mathrm{mm}$ in diameter) were placed on the agar surface and impregnated with $60 \mu \mathrm{l}$ of extract (dissolved in DMSO, in concentration of $40 \mathrm{mg} / \mathrm{cm}^{3}$ ) in aseptic conditions.

The plates were incubated for 24 hours at $37{ }^{\circ} \mathrm{C}$ for bacteria, and 48 hours at $25{ }^{\circ} \mathrm{C}$ for fungi. After incubation, the inhibition zone diameters, including the disc, were measured and expressed in $\mathrm{mm}$. Standardized discs of Ampicilin (10 $\mu \mathrm{g} / \mathrm{disc})$, Cephalexin $(30 \mu \mathrm{g} / \mathrm{disc})$ (Bio Rad) and Nystatin (100 U/disc) (Bioanalyse) $5 \mathrm{~mm}$ diameter were used as positive, and DMSO was used as negative control.

\section{Results and discussion}

The yield of total extractive matter (TEM), as well as total phenolics (TP) and total flavonoids (TF) content were determined in the aqueous earth smoke extract and the obtained results are shown in Table 2 .

Table 2. The yield of total extractive matter, total phenolics and total flavonoids content of the aqueous earth smoke extract

\begin{tabular}{cc}
\hline Total extractive matter, g/100 g p.m. & $23.20 \pm 1.18$ \\
Total phenolics, mg GAE/g p.m. & $77.67 \pm 1.20$ \\
Total flavonoids, mg RE/g p.m. & $21.21 \pm 1.83$ \\
\hline
\end{tabular}

The higher content of TP compared to TF was determined in the extract. Ivanov and coworkers (2014) have shown that the ethanolic extract of earth smoke from the territory of Bulgaria has a higher content of phenols 
(30.30 mg GAE/g of dry weight) and flavonoids (15.01 $\mathrm{mg} Q \mathrm{QE} / \mathrm{g}$ of the dry weight) compared to the extracts of nine other Fumaria species [6]. The TP content of the aqueous extract obtained in this work is significantly higher compared to the ethanolic extract described by Ivanov et al. [6], while the flavonoids content is very similar (Table 2). The usage of various extraction solvents, as well as plant materials from different areas has probably caused the observed difference.

It is known that phenolic compounds are bioactive molecules which possess antioxidant, anticancerogenic, antimicrobial and anti-inflammatory properties [17,18,19]. Having in mind the increasing significance of phenolic compounds because of their numerous in vivo positive biological effects, the growing needs of a detailed plant extracts analysis and the main bioactive components identification are not surprising.

The identification of the phenolic compounds present in the aqueous earth smoke extract was carried out using the ultrahigh performance liquid chromatography-diode array-electrospray ionization mass spectrometry method. Typical UHPLC-DAD chromatograms measured at $\lambda_{\text {mon }}=330 \mathrm{~nm}$ and ESI MS chromatograms ranged by $\mathrm{m} / \mathrm{z}$ of the base peaks (corresponding to molecular ions) were shown in Figure 1a and 1b, respectively. The list of detected compounds with the corresponding UV-Vis and MS-data is shown in Table 3.

Seven compounds have been detected in the extract while two of them were identified as rosmarinic and caffeic acid. The most intensive peak in chromatogram corresponds to rosmarinic acid (Figure 1, comp. No.6), identified as the main component in the extract. The identification of rosmarinic acid was done using rosmarinic acid standard and comparing the UV-Vis and MS-spectral data to the results from the available literature $[20,21]$.
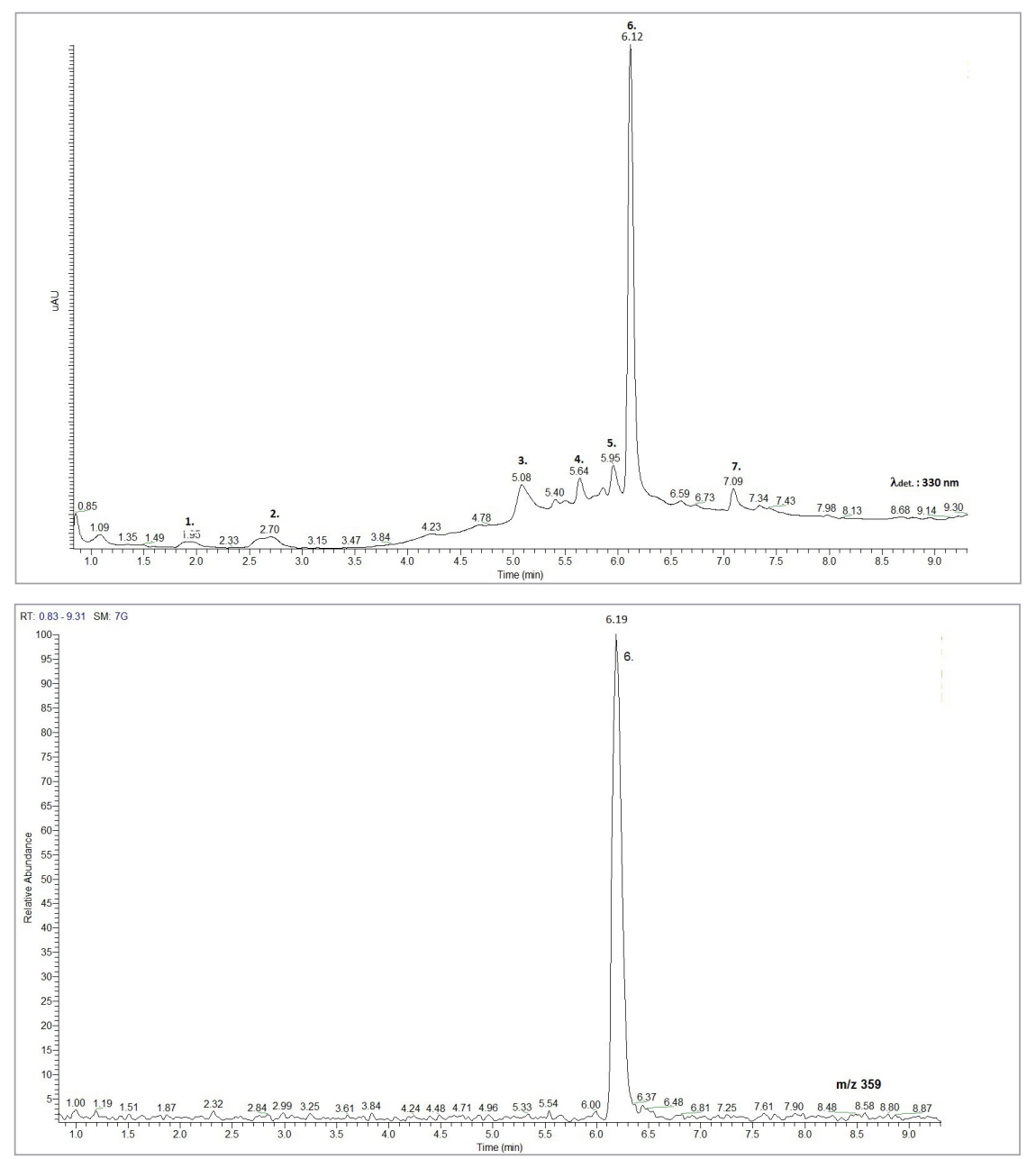

Figure 1. UHPLC-chromatogram of the aqueous earth smoke extract: DAD-signal monitored at $\lambda_{\text {mon }}=330 \mathrm{~nm}(\mathrm{a})$, and MS-chromatogram by selected mass of rosmarinic acid (b) 
Table 3. The compounds indentified in the aqueous earth smoke extract

\begin{tabular}{|c|c|c|c|c|c|}
\hline $\begin{array}{c}\text { Peak } \\
\text { number }\end{array}$ & $\begin{array}{c}\mathbf{t}_{R} \\
\min \end{array}$ & $\lambda_{\max }$ & $\begin{array}{c}m / z \\
{[M-H]^{-}}\end{array}$ & MS/MS & Component \\
\hline 1 & 1.94 & $310,280 \mathrm{~nm}$ & - & - & - \\
\hline 2 & 2.71 & $325 \mathrm{~nm}$ & 179 & - & Caffeic acida \\
\hline 3 & 5.08 & $276,222 \mathrm{~nm}$ & - & - & - \\
\hline 4 & 5.64 & $334,268 \mathrm{~nm}$ & - & - & - \\
\hline 5 & 5.95 & $326,287,217 \mathrm{~nm}$ & 745 & $\begin{array}{l}583(100 \%) \\
539,367\end{array}$ & - \\
\hline 6 & 6.12 & $330,290,220 \mathrm{~nm}$ & 359 & $\begin{array}{l}197,179,161(100 \%) \\
133\end{array}$ & $\begin{array}{c}\text { Rosmarinic } \\
\text { acid }^{b}\end{array}$ \\
\hline 7 & 7.09 & $316 \mathrm{~nm}$ & & - & - \\
\hline
\end{tabular}

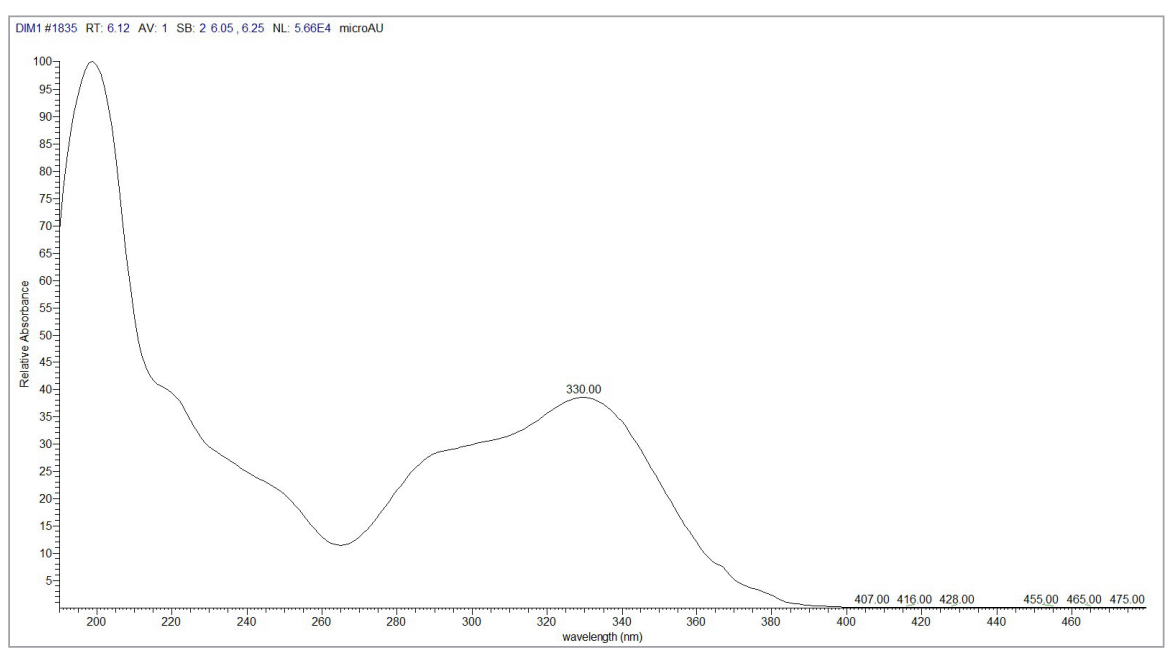

Figure 2. UV/Vis spectrum of rosmarinic acid in the extract of the earth smoke herb (component 6 in Figure 1a)

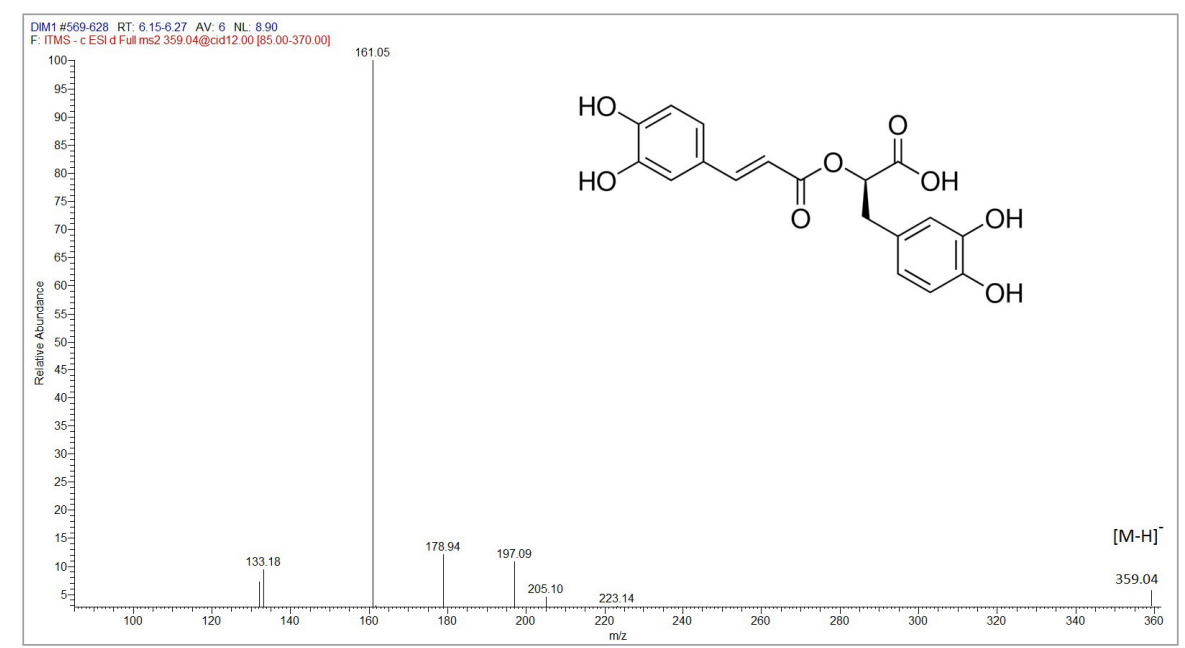

Figure 3. Mass spectrum of rosmarinic acid in the extract of the earth smoke herb (component 6 in Figure 1a) 
Based on the literature data, several HPLC $[22,23,24]$, LC/MS $[25,26,27]$ and spectrophotometric [28] methods have been developed in order to determine the concentration of rosmarinic acid in plant extracts. The concentration of rosmarinic acid in plant isolates is usually very low, while the extracts are often very complex mixtures which require the use of modern analytical methods.

UV/Vis spectrum of rosmarinic acid in the earth smoke herb extract (component 6 in Figure 1a) is shown in Figure 2; mass spectrum of the same compound is shown in Figure 3.

Taking into account its already known positive bioactivity, rosmarinic acid is targeted as a very important compound [29]. It was identified and quantified in the aqueous extract using UHPLC-DAD-ESI-MS method. According to retention time $\left(t_{R}=6.12 \mathrm{~min}\right.$; Figure 1a), MS-chromatogram by selected mass of rosmarinic acid (Figure 1b), UV/Vis spectrum (Figure 2) and the adequate MS/MS fragmentation of molecular ions (Figure 3) detecting $\mathrm{m} / \mathrm{z}$ 197, 179 and 161 fragments (Table 3), compound 6 shown in Figure 1 has been identified as rosmarinic acid. The standard of rosmarinic acid, as well as the literature data published earlier [21], has also been used in the identification of compound 6 .

The calibration curve of rosmarinic acid was constructed (Figure 4) in order to determine its concentration in the obtained extract. The experiment was performed in five repetitions and the mean values \pm standard deviations are presented in the graphs.

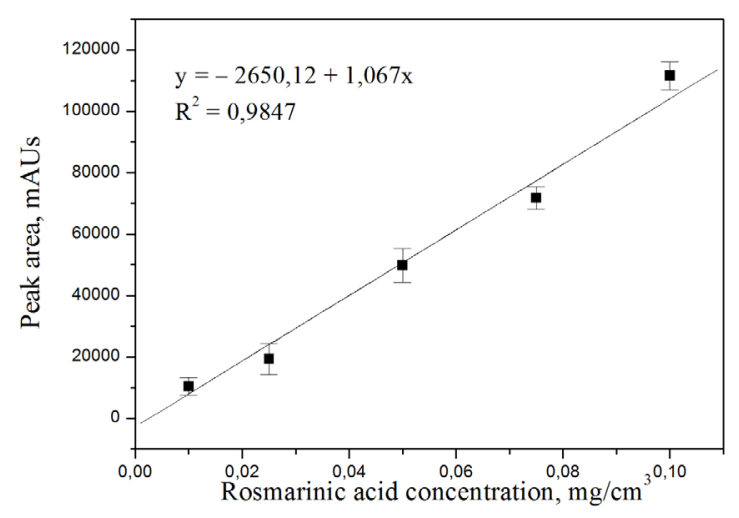

Figure 4. The calibration curve of rosmarinic acid constructed according to data from chromatograms measured at $\lambda_{\text {mon }}=330$ $\mathrm{nm}$

The UHPLC chromatogram of rosmarinic acid standard dissolved in methanol is shown in Figure 5. Rosmarinic acid was identified at retention time of $6.12-6.24$ min.

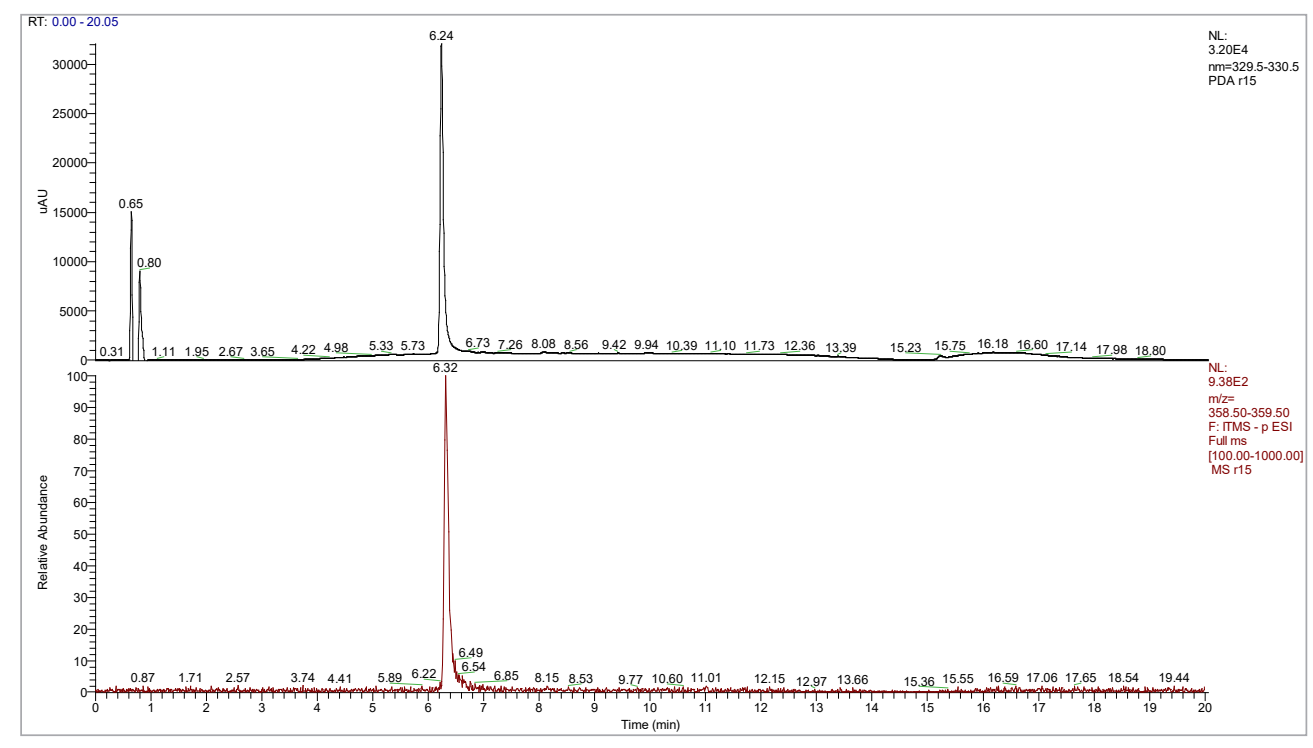

Figure 5. UHPLC chromatogram of rosmarinic acid in methanol: DAD-signal at $\lambda_{\text {mon }}=330 \mathrm{~nm}$ (upper part) and MS-chromatogram monitored by rosmarinic acid mass (lower part)

The obtained UV-Vis (a) and mass spectra (b) of rosmarinic acid are shown in Figure 6. By configuration, the electronic absorption spectrum of rosmarinic acid corresponds to the spectra of phenolic acids where it belongs as a derivative of caffeic acid and 2-hydroxy derivative of hydroxycaffeic acid: a maximum at $329 \mathrm{~nm}$ and a shoulder at $290 \mathrm{~nm}$ (Figure 6a). The mass spectrum of rosmarinic acid shows three major fragmentation ions at $\mathrm{m} / \mathrm{z} 197,179$ and 161 (Figure 6b) originating from molecular ion at $m / z 359[\mathrm{M}-\mathrm{H}]-$ and corresponding to main rosmarinic acid constituents - dihydrocaffeic acid derivative, caffeic acid and a fragment formed by the water molecule elimination from the $\mathrm{m} / \mathrm{z} 179$ ion, respectively [21]. 


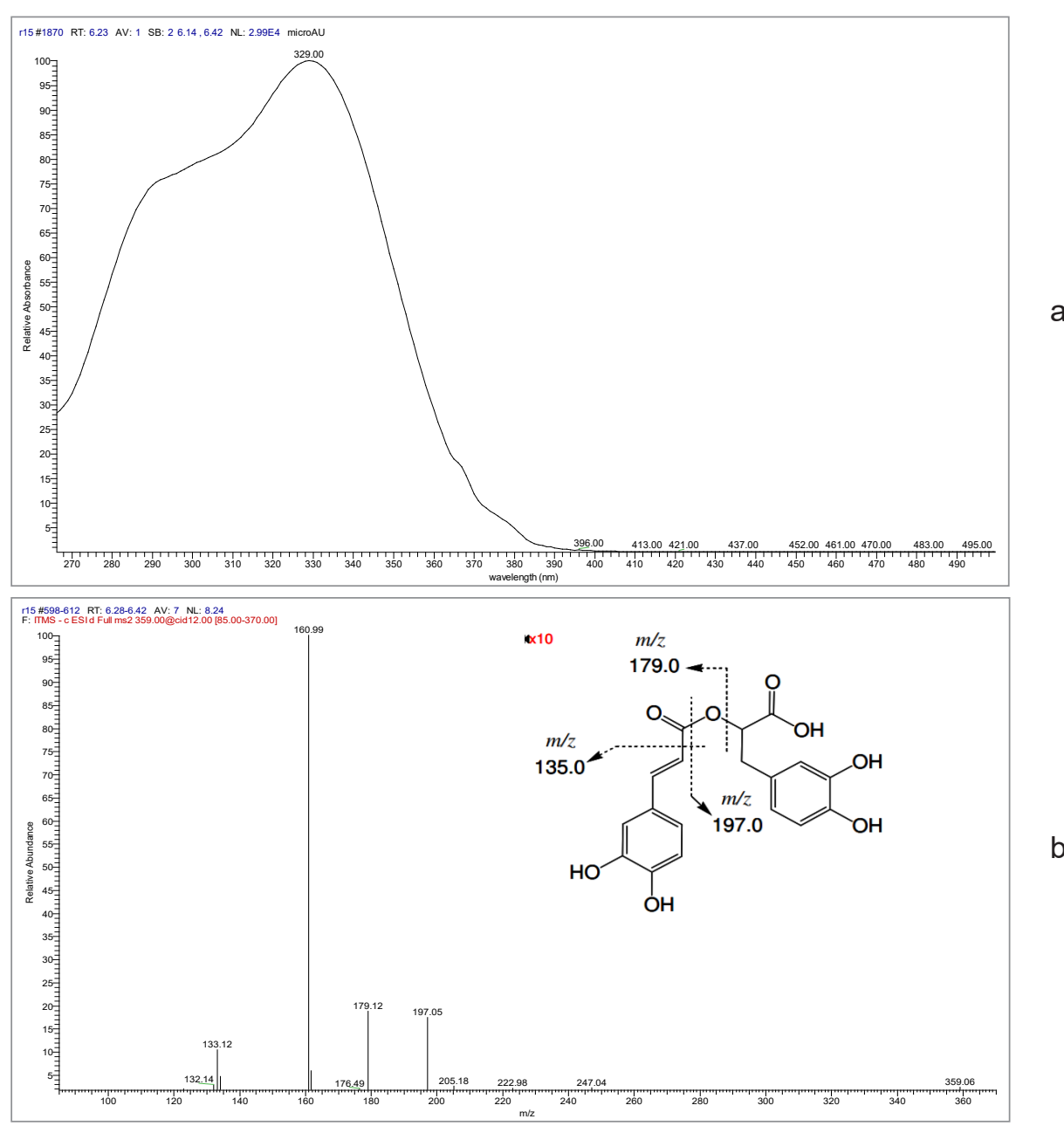

Figure 6. UV-Vis (a) and mass spectrum (b) of rosmarinic acid

According to the calibration curve, the concentration of rosmarinic acid in the aqueous extract (Fig. 4) was determined to be $1.94 \mathrm{mg} / \mathrm{cm}^{3}$, i.e. its content calculated per gram of the dry extract is $16.7 \mathrm{~g} / 100 \mathrm{~g}$, which implies that rosmarinic acid is present in a relatively large percentage. Rosmarinic acid is isolated from rosemary leaf for the first time [30]. Plants containing rosmarinic acid, as Rosmarinus officinalis and Sanicula europea, are used in the cosmetic industry due to their antioxidant properties originating from rosmarinic acid itself [29]. Many biological properties of rosmarinic acid are known: astringent effect, antiinflammatory, antimutagenic, antibacterial and antiviral activity. The extract of lemon balm, which also contains rosmarinic acid, is used in the therapy of Herpes simplex [29]. Several studies have shown that rosmarinic acid could be introduced as a new therapeutic agent in the atopic dermatitis treatment [30], making the results presented in this work exceptionally valuable, leading to the conclusion that the aqueous extract of the earth smoke herb represents a valuable source of rosmarinic acid potentially applicable in pharmaceutical and cosmetic industry.

Furthermore, the aqueous earth smoke extract has been subjected to the antioxidant activity testing by two different systems, DPPH and ABTS test. The scavenging capacity of DPPH and ABTS radical in the function of the extract concentration is presented in Figures 7 and 8, respectively, while the $\mathrm{EC}_{50}$ values of the extract and standard antioxidant are shown in Table 4.

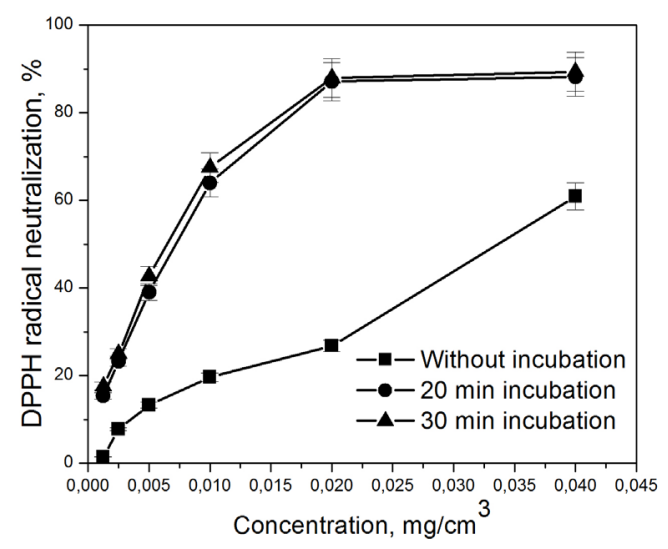

Figure 7. The capacity of DPPH radical neutralization by the aqueous extract of the earth smoke herb 


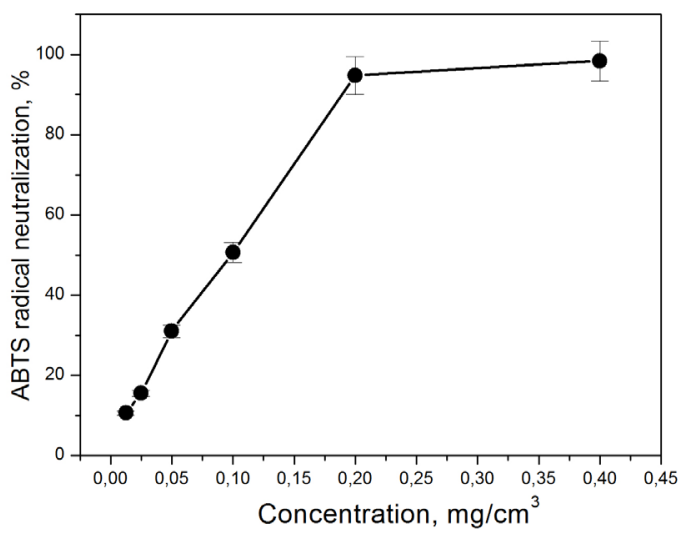

Figure 8. The capacity of ABTS radical neutralization by the aqueous extract of the earth smoke herb

Table 4. The $\mathrm{EC}_{50}$ values for the aqueous earth smoke extract and synthetic antioxidant $\mathrm{BHT}$

\begin{tabular}{|c|c|c|}
\hline \multicolumn{3}{|c|}{$\mathrm{EC}_{50}, \mu \mathrm{g} / \mathrm{cm}^{3}$ (DPPH test) } \\
\hline & Without incubation & $48.6 \pm 1.85$ \\
\hline & 20 min incubation & $8.18 \pm 1.35$ \\
\hline & 30 min incubation & $7.38 \pm 1.05$ \\
\hline $\mathrm{BHT}$ & 20 min incubation & $21.0 \pm 1.0$ \\
\hline \multicolumn{3}{|c|}{$\mathrm{EC}_{50}, \mu \mathrm{g} / \mathrm{cm}^{3}$ (ABTS test) } \\
\hline Extract & \multicolumn{2}{|c|}{$96.0 \pm 2.15$} \\
\hline $\mathrm{BHT}$ & \multicolumn{2}{|c|}{$81.0 \pm 1.0$} \\
\hline
\end{tabular}

Many investigations have reported high linear correlation between the antioxidant activity of different plant extracts and total phenolics and flavonoids in the extracts $[31,32]$. Having in mind that rosmarinic and caffeic acids, well known as good antioxidants [17,18,19], have been identified in the aqueous earth smoke extract (Table 3), as well as that a relatively high content of rosmarinic acid has been determined, it could be expected that the antioxidant activity due to these compounds presence, but it is most likely that the antioxidant activity comes from a synergistic effect of all bioactive components isolated from the plant material, with or without the antioxidant activity.

Ethanolic extracts of aerial parts from different Fumaria species from Bulgaria [6] and the methanolic extract of aerial parts from F. officinalis from Turkey [1] showed the antioxidant activity which is in accordance with our results [6]. At the same time, the ethanolic extract from $F$. officinalis showed a lower antioxidant activity compared to the aqueous extract in this study probably because of different chemical composition [6].

The aqueous extract obtained from the earth smoke herb showed a better antioxidant activity than synthetic antioxidant BHT (Table 4). Previous studies reviewed that $\mathrm{BHT}$ is one of the most commonly used antioxidants with harmful effects on humans [33]. According to the re- sults presented in this study, the obtained extract could be considered as a natural alternative to $\mathrm{BHT}$ with potential application in pharmaceutical, cosmetic and food industry.

The aqueous extract of the earth smoke herb has shown the antimicrobial activity against four tested microorganisms: $C$. albicans, $P$. vulgaris, $P$. aeruginosa and K. pneumoniae (Table 5).

Table 5. Antimicrobial activity of the aqueous earth smoke extract

\begin{tabular}{lcccc}
\hline \multicolumn{1}{c}{ Microorganism } & \multicolumn{4}{c}{ Inhibition zone, $\mathbf{m m}$} \\
& Extract & Amp & Ceph & Nys \\
\hline C. albicans & 23 & n.t. & n.t. & 17 \\
P. vulgaris & 18 & 13.2 & n.t. & n.t. \\
P. aeruginosa & 16 & n.t. & n.t. & n.t. \\
B. subtilis & n.e. & n.t. & 48 & n.t. \\
K. pneumoniae & 15 & n.t. & 13 & n.t. \\
S. aureus & n.e. & 36.7 & 26 & n.t. \\
E. coli & n.e. & n.t. & 26 & n.t. \\
\hline Amp-Ampicilin; Ceph-Cephalexin; Nys-Nystatin; n.e. - no effect; n.t.-no treated &
\end{tabular}

The highest antimicrobial activity of the aqueous earth smoke extract was observed against $C$. albicans and $P$. vulgaris. Sengul and coworkers (2009) reported that the methanolic extract of the aerial part of earth smoke showed a moderate antimicrobial activity against a large number of microorganisms. On the other hand, in the same research, the aqueous extract had no or very low activity against the same microorganisms [1]. In the research of Erdoğrul (2002) ethyl acetate, methanol, chloroform and acetone extracts of Fumaria officinalis showed no activity against 12 analyzed microorganisms [34]. The results of antimicrobial activity of the aqueous earth smoke extract presented in this paper should not be neglected. It can be assumed that it is a result of a synergistic effect of different bioactive compounds of the extract since a biological activity of rosmarinic acid is already well known [29]. According to the results obtained, the aqueous earth smoke extract could be used for the production of phytopharmaceutical formulations with antimicrobial activity.

\section{Conclusion}

In conclusion, two components are identified in the aqueous earth smoke extract: caffeic and rosmarinic acid. The aqueous extract of earth smoke herb showed the antioxidant activity in vitro, demonstrated by DPPH and ABTS tests. This study promotes the potential of the earth smoke grown in Serbia, as a promising source of valuable phenolic compounds with high antioxidant potential and health beneficial properties. Further, the prepared extract has shown the antimicrobial activity against four microorganisms: C. albicans, P. vulgaris, $P$. aeruginosa and $K$. pneumoniae. The highest antimicrobial activity has been expressed against $C$. albicans fungus. Based on the above, the obtained earth smoke extract is a source of natural antioxidants and antimicro- 
bial agents, e.g. natural products with the potential application in food, pharmaceutical and cosmetic industry. It could be taken into account as natural alternative to synthetic additives, expanding the applications of the earth smoke extract from ethnomedicine to the industrial use as a food and cosmetics preservative.

\section{Acknowledgements}

This work was supported by the Ministry of Education, Science and Technological Development of the Republic of Serbia under the Project on Development of Technology number TR-34012.

\section{List of abbreviations}

Total extractive matter - TEM
Total phenolics - TP
Total flavonoids - TF
GAE - galic acid equivalent
RE - rutin equivalent
d.e. - dry extract
p.m. - plant material

\section{References}

[1] M. Sengul, H. Yildiz, N. Gungor, Z. Eser, S. Ercisli, Total phenolic content, antioxidant and antimicrobial activities of some medicinal plants, Pakistan Journal of Pharmaceutical Sciences, 22(1) (2009) 102-106.

[2] J.A. Duke, M.J. Bogenschutz-Godwi, J. duCellier, P.-A. K. Duke, Handbook of Medicinal Herbs, CRC Press LLC, 2002.

[3] J. Tucakov, Lečenje biljem, RAD-Beograd, Beograd, 1997 (In Serbian).

[4] F. Capasso, T.S. Gaginella, G. Grandolini, A.A. Izzo, Fitoterapija - Priručnik biljne medicine, Prometej, Novi Sad, 2005 (In Serbian).

[5] B. Dulger, A. Gonuz, Antimicrobial Activity of Ceratin Plants used in Turkish Traditional Medicine, Asian Journal of Plant Sciences, 3(1) (2004)104-107.

[6] I.G. Ivanov, R.Z. Vrancheva, A.S. Marchev, N.T. Petkova, I.Y. Aneva, P.P. Denev, V.G. Georgiev, A.I. Pavlov, Antioxidant activities and phenolic compounds in Bulgarian Fumaria species, International Journal of Current Microbiology and Applied Sciences, 3(2) (2014) 296-306.

[7] P.Mattila, J.J. Kumpulainen, Determination of free and total phenolic acids in plant derived foods by HPLC and diode array detection, Journal of Agricultural and Food Chemistry, 50(13) (2002), 3660-3667.

[8] R.J. Robbins, Phenolic Acids in Foods: An Overview of Analytical Methodologfy Journal of Agricultural and Food Chemistry, 51(10) (2003) 2866-2887.

[9] V.L. Singleton, J.A. Rossi, Colorimerty of total phenolics with phosphomolybdic-phosphotungstic acid reagents, American Journal of Enology and Viticulture, 16 (1965) 144-158.

[10] Lj. Stanojević, M. Stanković, V. Nikolić, Lj. Nikolić, D. Ristić, J. Čanadanovic-Brunet, V. Tumbas, Antioxidant activity and total phenolic and flavonoid contents of Hieracium pilosella L. extracts. Sensors, 9 (2009) 5702-5714.

[11] J.-Y. Lin, C.-Y. Tang, Determination of total phenolic and flavonoid contents in selected fruits and vegetables, as well as their stimulatory effects on mouse splenocyte proliferation. Food Chemistry, 101 (2007) 140-147.

[12] Lj.P. Stanojević, J.S. Stanojević, D.J. Cvetković, M.D. Cakić, D.P. Ilić, Antioxidant activity of ethanolic extract from cultivated strawberries leaves (Fragariae folium), Hemijska Industrija, 69(5) (2015) 567-576 (In Serbian).

[13] R. Re, N. Pellegrini, A. Proteggente, A. Pannala, M. Yang, C. Rice Evans, Antioxidant activity applying an improved ABTS radical cation decolorization assay, Free Radical Biology Medicine, 26 (1999) 1231-1237.

[14] S. Dudonne, X. Vitrac, P. Coutiere, M. Woillez, J.-M. Merillon, Comparative Study of Antioxidant Properties and Total Phenolic Content of Plant Extracts of Industrial Interest Using DPPH, ABTS, FRAP, SOD, and ORAC Assays. Journal of Agricultural and Food Chemistry, 57 (2009)1768-1774.

[15] Isenberg H.D., Clinical Microbiology Procedures Hanbook, Second Edition. ASM Press, Washington D.C., USA, 2004

[16] V. Lorian, Antibiotics in Laboratory Medicine. Fifth Edition. Lippincott Williams \& Wilkins, Philadelphia, USA, 2005.

[17] K.J. Meyers, C.B. Watkins, M.P. Pritts, R.H. Liu, Antioxidant and antiproliferative activities of strawberries, Journal of Agricultural and Food Chemistry, 51(23) (2003) 6887-6887.

[18] P.G. Pietta, Flavonoids as antioxidants, Journal of Natural Products, 63(7), (2000) 1035-1042.

[19] P. Wu, C. L. Marimuthu, H. T. Chang, S. T. Chang, Journal of the Science of Food and Agriculture, 88(8) (2008) 1400-1405.

[20] U. Justesen, Negative atmospheric pressure chemical ionisation low-energy collision activation mass spectrometry for the characterisation of flavonoids in extracts of fresh herbs, Journal of Chromatography A, 902 (2000) 369-379.

[21] M.B.Hossain, D.K. Rai, N.P. Brunton, A.B. Martin-Diana, C. Barry-Ryan, Characterization of Phenolic Composition in Lamiaceae Spices by LC-ESI-MS/MS, Journal of Agricultural and Food Chemistry, 58, (2010)10576-10581.

[22] V.Canelas, C.T. da Costa, Quantitative HPLC Analysis of Rosmarinic Acid in Extracts of Melissa officinalis and Spectrophotometric Measurement of Their Antioxidant Activities, Journal of Chemical Education, 84(9) (2007) 1502-1504.

[23] B.J. Liu, Y. Wan, Z. Zhao, H. Chen, Determination of the content of rosmarinic acid by HPLC and analytical comparison of volatile constituents by GC-MS indifferent parts of Perilla frutescens (L.), Chemistry Central Journal 7(61) (2013) 1-11.

[24] S.-S. Chun, D.A. Vattem, Y.-T. Lin, K. Shetty, Phenolic antioxidants from clonal oregano (Origanum vulgare) with antimicrobial activity against Helicobacter pylori, Process Biochemistry 40 (2005) 809-816.

[25] L. Almela, B. Sanchez-Munnoz, J.A. Fernandez-Lopez, M.J. Roca, V. Rabe, Liquid chromatograpic-mass spectrometric analysis of phenolics and free radicals cavenging activity of rosemary extract from different raw material, Journal of Chromatography A, 1120 (2006) 221 229.

[26] D. Bandoniene, M. Murkovic, P.R. Venskutonis, Determination of Rosmarinic Acid in Sage and Borage Leaves by High-Performance Liquid Chromatography with 
Different Detection Methods, Journal of Chromatographic Science, 43(1-5) (2005) 372-376.

[27] H. Wang, G.J. Provan, K. Helliwell, Determination of rosmarinic acid and caffeic acid in aromatic herbs by HPLC, Food Chemistry 87 (2004) 307-311.

[28] T. Lopez-Arnaldos, M. Lopez-Serrano, A. Ros Barcelo, A.A. Calderon, J.M. Zapata, Spectrophotometric determination of rosmarinic acid in plant cell cultures by complexation with $\mathrm{Fe}^{2+}$ ions, Fresenius Journal of Analytical Chemistry, 351 (1995) 311-314.

[29] M. Petersen, M.S. Simmonds, Rosmarinic acid, Phytochemistry, 62(2) (2003)121-125.

[30] N. Kovačević, Osnovi farmakognozije, Srpska školska knjiga, Beograd (2004).

[31] Lj.P. Stanojević, A.S. Zdravković, M.Z. Stanković, M.D. Cakić, V.D. Nikolić, D.P. Ilić, The antioxidant activity of aqueous-ethanolic extracts from nettle leaf (Urtica dioica L.). Advanced technologies, 2(1) (2013) 51-59 (In Serbian).
[32] I.T. Karabegović, S.S. Stojičević, D.T. Veličković, Z.B., Todorović, N.Č. Nikolić, M.L., Lazić, The effect of different extraction techniques on the compositionand antioxidant activity of cherry laurel (Prunus laurocerasus) leaf and fruit extracts, Industrial Crops and Products, 54 (2014) 142-148.

[33] N. Ito, M. Hirose, H. Fukushima, T. Tsuda, T. Shirai, M. Tatenatsu, Studies on antioxidants: Their carcinogenic and modifying effects on chemical carcinogens, Food and Chemical Toxicology, 24 (1986) 1071-1092.

[34] Ö.T. Erdoğrul, Antibacterial Activities of Some Plant Extracts Used in Folk Medicine, Pharmaceutical Biology, 40(4) (2002) 269-273.

Izvod

\section{ANTIOKSIDATIVNA I ANTIMIKROBNA AKTIVNOST VODENOG EKSTRAKTA DIMNJAČE (Fumaria officinalis L.)}

Ljiljana Stanojević1, Jelena Zvezdanović ${ }^{1}$, Bojana Danilović1, Dragan Cvetković1, Jelena Stanojevićn ${ }^{1}$, Dušica Ilić ${ }^{2}$, Milorad Cakić ${ }^{1}$

(ORIGINALNI NAUČNI RAD) UDK 582.675.5:615.322:66.061

${ }^{1}$ Tehnološki fakultet, Leskovac, Univerzitet u Nišu, Srbija

2 Istraživačko-razvojni centar „ALFATEC“ doo, Niš, Srbija

U istraživanju je korišćen nadzemni deo dimnjače (Fumaria officinalis L.) kao ekstrakcioni materijal. Biljni materijal je preliven ključalom vodom pri hidromodulu $1: 20 \mathrm{~m} / \mathrm{v}$ i ostavljen da stoji 90 min na sobnoj temperaturi u cilju dobijanja vodenog ekstrakta. Identifikacija bioaktivnih komponenti u ekstraktu izvršena je primenom UHPLC-DAD-ESI-MS analize. Sadržaj ukupnih fenola i ukupnih flavonoida određen je spektrofotometrijski metodom po Folin-Ciocalte-u i metodom sa $\mathrm{AlCl}_{3}$, respektivno. Antioksidativna aktivnost je takođe određena spektrofotometijski primenom DPPH i ABTS testa. Antimikrobna aktivnost ekstrakta određena je diskdifuzionom metodom na sledeće patogene mikroorganizme: Candida albicans, Proteus vulgaris, Pseudomonas aeruginosa, Bacillus subtilis, Staphylococcus aureus, Escherichia coli i Klebsiella pneumoniae. U ekstraktu je registrovano sedam komponenti, dok su identifikovane dve, kafeinska i ruzmarinska kiselina. Najzastupljenija komponenta u ekstraktu je ruzmarinska kiselina (16,7 g/100 g suvog ekstrakta). Sadržaj ukupnih fenola je bio $77,67 \mathrm{mg} E G K / g$ suvog ekstrakta, dok je sadržaj ukupnih flavonoida bio $21,21 \mathrm{mg}$ ER/g suvog ekstrakta. Koncentracija ekstrakta potrebna za neutralisanje $50 \%$ od početne koncentracije DPPH radikala nakon 30 min inkubacije, 20 min inkubacije i neposredno nakon dodavanja DPPH radikala iznosila je 7,38; 8,18 i $48,6 \mu \mathrm{g} / \mathrm{cm}^{3}$, respektivno, dok je potrebna koncentracija za neutralisanje $50 \%$ od početne koncentracije ABTS radikala iznosila 96,0 $\mathrm{\mu g} / \mathrm{cm}^{3}$. Ekstrakt je pokazao najbolju antioksidativnu aktivnost na gljivu Candida albicans. Prezentovani rezultati pokazuju da dobijeni vodeni ekstrakt nadzemnog dela dimnjače predstavlja potencijalni izvor prirodnih antioksidanasa i antimikrobnih agenasa.
Ključne reči: Fumaria officinalis L.; Vodeni ekstrakt dimnjače; Antioksidativna aktivnost; Antimikrobna aktivnost; Ruzmarinska kiselina. 